\title{
IMPLEMENTING PRINCIPAL LEADERSHIP ON PARENTING PROGRAM AT EARLY CHILDHOOD EDUCATION
}

\author{
Imron Arifin \\ Department of Educational Management, State University of Malang, Indonesia \\ imron.arifin.fip@um.ac.id
}

\begin{abstract}
Principal leadership in constructing school and family ties in the education of children in schools through a parenting program is important and necessary to support and encourage the growth and development of children. Parenting programs in early childhood mean that children's education is not only the responsibility of the school but rather a shared responsibility. The work is aimed to: know the principal's leadership in implementing parenting programs; forms of parenting programs implemented in early childhood education institutions. This study was designed with a qualitative approach. The data were collected through interviews, observation and documents. The results showed that the principal's leadership played a psycho-religious educators. In managerial principal's plan, implement, establish relationships, and conduct monitoring and evaluation of the parenting program. In the application of parenting found 5 program include: the group of parent meetings; the involvement of parents in the group; parental involvement in the event together; the consultation of parents; and home visits.
\end{abstract}

Keywords: early childhood education, parenting program, principal leadership

\section{INTRODUCTION}

Parenting program has been implemented in schools under the Directorate of Early Childhood Education (DoECE). The parenting program was introduced in 2012 as a program for the Institute of Early Childhood Education by the Directorate of Early Childhood. Parenting programs refer to various programs that allow sustainability and harmony between what is done at school and the parents in the home so that the child's education optimal [1].

Family environment is a vehicle for the first and primary education for every child. The first environment for the child since birth and growth to be in a family environment that influenced the climate, culture, and lifestyle of the family. Primary environment for most of the lives of children and to growing in the family, so that the basis of education, morality, social, cultural, religious and children are very influenced patterns and lifestyle of the family [2]. Early childhood education institutions as a neighborhood preschool education is a vehicle for growth and development of healthy children, intelligent, cheerful and noble role to play in the education process of children that has taken place within the family [3].

Associated with parental involvement in educational institutions. Parent involvement was designed to created a partnership that allowed for greater collaboration between home and school for the expressed purpose of improved student outcomes.22 It was intended to enhance the school's capacity to understand and appreciate values and cultures of families and be more effective in meeting student needs, to make sense of an active and participatory process parents will materialize as real activity when met three contributing factors namely lack of will, the ability and the opportunity to participate [4].

Henderson and Derson reported that research on the role of the family in the achievement of students who have done the most accurate predictor of a student's achievement in school is not income or social status [5]. However, the extent to the which that student's family is able to create a home environtment than encourages learning, express high (but not unrealistic) expectations for reviews their children's achievement and future careers, and become involved in their children's education at school and in the community.

The components and parent participation in school, contact with parent and satisfaction with parental involvement [6]. So that parent involvement in education have benefits for the children, the parents, the educators, and the school [4]. Research on parenting education at the level of early childhood education in Indonesia has rarely reported, of which have been implemented Hariawan who found the benefit program parenting achievement non-academic children [7], and Nuriati found parenting education specified participation factor, the belief in the benefits of the program, and learning andragogy [8]. Other researcher investigated that the development model of transformative learning effective parenting program if parents want to make changes themselves and function as a facilitator and counselor educator [9]. Furthermore, Desyanty reported that parents who are involved in parenting education will be effective if it has a physiological readiness, social maturity, and the recognition of the impact on the emergence of the group's commitment to learning followed by parents as learners [10].

Based on the above explanation, it can be understood that parents involvement in school programs has various positive benefits on children's education. However, research on the principal's leadership in the implementation of the program of parenting at the institute of early childhood education has rarely been reported. This work can guide the principal's role in involving parents in their children's education effectively to institute early childhood education in Indonesia. Therefore, it is important to investigate the principal's leadership in implementing parenting programs and other forms of parenting programs implemented in early childhood education institutions. 


\section{METHODS}

This study used a qualitative approach. The researcher is the main instrument in the process of data collection through interviews, observation and documents. All the data were collected to support the depth of focus of the research. The informants were searched and selected in order to obtain informations assosiatied to the purpose of research or discovery of key informant using the snowball sampling technique.

Data analysis was performed using a flow model analysis covering data collection, data reduction, display data, and conclussion or verifying. Checking validity of the data was done through the degree of credibility among other persistent observation, triangulation of resources, triangulation of techniques, triangulation of time, member check, and referential adequacy check. The checking was also carried out through dependability and confirmability.

\section{RESULTS AND DISCUSSION}

\section{A. Results}

1. Leadership Principal

Principal leadership plays a psycho-religious educators. In the communication and interaction between the principal and parent primary key contained in the trust. Trust will arise when the parents of the principal the field of child psychology, so that the parents feel they improved their knowledge of how to educate effectively based on the science of psychology. In addition, in communicating and interacting with parents, especially in the parenting program, the principals have been useed religious approach because the most parents embraced Islam in Indonesia. The ability of the principal in appreciating tarbiyatul lil aulad (islamic education for children) by communication influences and mobilizes parents to active and participate in education become the dominant factor.

The role of principals managerial has been done by planning, implementating, networking, monitoring and evaluating of the parenting program. Thera are 3 aspects strengthening the principals such as influencing and mobilizing parents to active and participate throught psycho-religious approach; building harmonious-positive relationships between the institution and parents; and cooperating with parent teacher association.

\section{Types of Parenting Program}

The parenting programs can be classified in 5 types, i.e. group parent meeting; parental involvement in the group; parental involvement in joint events; parent consultation day; and home visit. The types of parenting program are explained in more detail as the following paragraphs.

Group parent meeting (GPM) is a communication forum for parents to share information and knowledge of how to implement early childhood education at home. The principal becomes a facilitator to bridge the parents in improving the knowledge, attitudes, and skills of parents in implementing early childhood education at home. The GPM is also able to increase the willingness of parents who have young children to send their children to early childhood education institutions. Furthermore, it also provides readiness for families who do not have early childhood in implementing early childhood education. In general, the techniques used in the GPM are brainstorming, workshop, stimulation, and learn specific skills related to the children interests.

Involvement of parents in the group (IPG) is an activity that involves parents ( 1 or 2 parents) to assist teachers in the learning process in groups/children class. This activity is specifically subjected for parents whose children in early childhood institutions. The parents serves as teacher assistant in early childhood institutions. This activity can improve social and emotional bond between parents, teachers and children; enhance the understanding of parents way in educating early childhoods; improve the understanding of parents about their children's behavior during the learning process for providing positive support to the development of the children; and increase parents' understanding of the tasks of teachers in order to better appreciate and increase support for the institution. The role of the principal coordinates parents and teachers to cooperate in managing the group/class starting from organizing the tools to play, when to play, and after the games based on the standard operating procedures.

Parental involvement in the joint events (PIJE) are activities that involve parents in the learning support implementation of activities undertaken in the outing activities. This activity is helpful close relationship between parents, children, and educational institutions; enhance the role of parents in the learning process. Event types include: parenting day, mother day, father day, family day, and outbound; excursion to praying house, post office, police office, supermarket, museum, home industry; gardening, harvesing, until the family inn. The role of principals formed a committee consisting of teachers and parents to manage these activities.

Consulting days parents (CDP) are certain days that are scheduled by the principal as the meeting between the parents with school principals and psychologists to discuss the growth and development of children as well as other problems facing children. This activity is helpful to solve the problems facing children; increase the awareness of parents about the importance of attention to grow and develop early childhood; and improve the ability of parents in making early childhood education in the family. Consultations were carried out individually (family) in the space provided or group of families in a family consultation events together, especially to early detection of growth. All the results of the consultations were recorded as an evaluation and follow up.

Home visit (HV) is activity relationship between inter-parent or with principal/educator to useful home parent bonding, visit, or in order to give/ask for specific support is done amicably. The purpose of this activity to establish a relationship between families and institutions; dig up information about the patterns of parental education in the family; find solutions together to the problems faced by parents 
in the home; and build positive habits of children when there is a visit at home. The school principal design the program home visit and moving home. Home visit conducted principals and teachers, or one of them with prior arrangement. Moving home is special for children and teachers visit together to the home of the child/family in order to familiarize themselves with the specific culture of family and friends' houses.

Based on the observations of the principal's leadership in establishing the role of parents in early childhood education, the findings of this study can be described as follows:

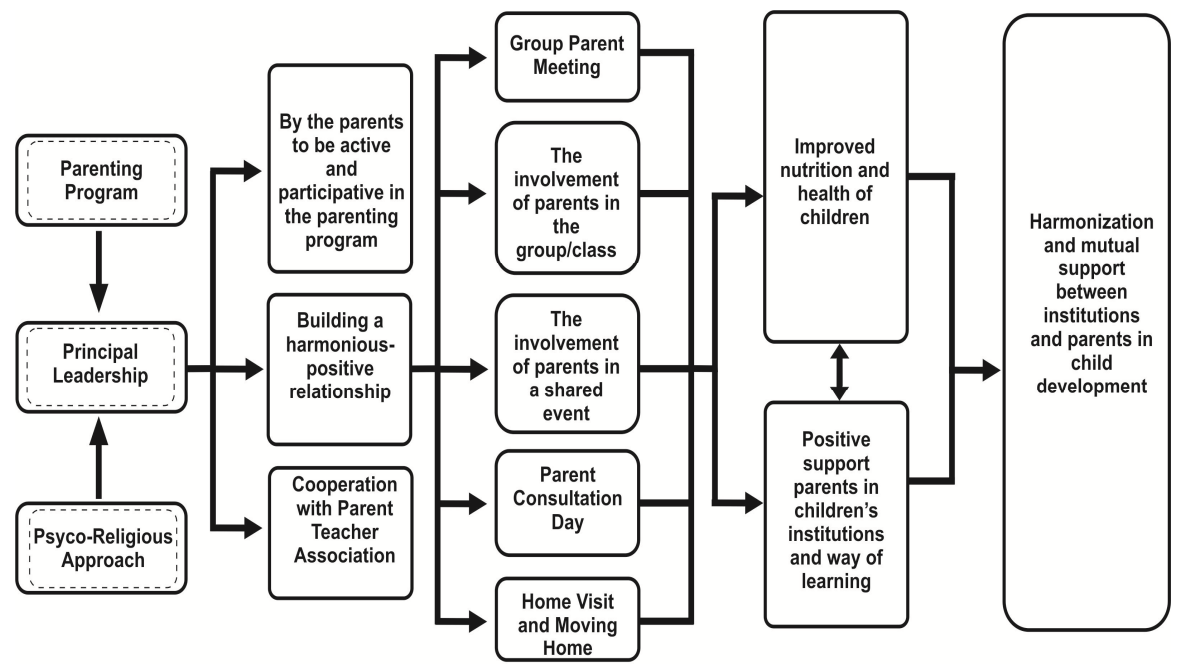

Figure 1. Principal Leadership in Early Childhood Parenting Program

\section{B. Discussion}

Principal leadership plays a key role in the success of affecting, moving, and building relationships and communication with parents through parenting programs in early childhood education environment with Psycho-religious approach. These findings are relevant that the relationship between schools and families effective if the principal is able to establish communication and interaction positive and harmonious. The principal function of leadership influence and mobilize parents so consciously want to do to the purpose of the school and are able to create change effectively in a group [11].

Psycho-religious leadership can build parent confidence in the competence of personality, social, pedagogical, and professional principals. Because the principal is considered to have pedagogy, psychology, sociology, professional attitude, even appreciation of good faith. Religious leadership is effective in building relationships with the family, because it was accompanied gentle nature, avoid harsh words and hard, avoid hardness of heart (ghildhatu al-qalbi), forgiving (al-'afwu), ask for forgiveness, deliberation (shura'), determination ('Azimah), no doubt, and trust in Allah [12]. Religious leadership is expressed through religious activity, dedication, belief and religion implementation. In a more narrow sense of religious leaders to apply the provisions of religion in daily life at home, at work, in relationships with parents, the community and even the behavior of nature [13].

Principal in influence, connect and empower the role of parents is directed and emphasized harmony with the policies and programs of the school or early childhood education institutions, as well as oriented to the interests of the child. Shrewdness of the principal influence parents to be active and participative in the parenting program. this is in accordance with the expression of the meaning of leadership that the leadership as influence the processes affecting the interpretation of the event for the follower, the choice of objectives for the group or organization, the organization of work activities to Accomplish the objectives, the motivation of followers to achieve the objectives, the maintenance of cooperative relationships and teamwork and the enlistment of the support and cooperation from people outside the group or organization [14].

Expertise principals in touch and cooperate with parents indicate certain skills in the early childhood education, of which four clusters of skills were identified as contributing to better job performance in their management and leadership roles, interpersonal and communication skills, group facilitation skills, decision-making skills, and staff development skills [15]. The onus is on early childhood professionals to find the best way to get know each family and negotiate the most effective means of staying in contact with them, as part of communication skill [16].

Forms of parenting activities program through group parent meetings, parent involvement in the group, the involvement of parents in the event together, the consultation of parents and home visits have the same principles as the expression Olsen and Fuller on the role of parents in children is basic responsibilities of families; communication; volunteering; learning at home; decicion making; and collaborating with family [4]. Of the activities in question in accordance with the parenting program, as revealed that parent come to 
parent education with many different goals and beliefs about parenting. They are looking for ideas and support to be good parent. Some people still believe that parent education classes only because they have problems managing reviews their children behavior [17].

Related to parenting program, finding of distinguishes four categories of partnerships between schools and communities, namely (1) networking, a partner in the mutual exchange of information without disturbing each other, (2) coordination, a partner in the formal agreement to coordinate the various activities, (3) cooperation, a partner in the formal agreement and cooperation in specific areas, and (4) collaboration, partner agreed and are committed to sharing power and authority in the implementation of programs or activities [18]. Other expert suggests there are 6 types, including: (1) the basic responsibilities of the family, (2) communication, (3) volunteer, (4) learning at home, (5) decision-making, and (6) collaboration with the community [19]. Further showed that the components and elements of the participation of parents/guardians of students include: "emphasis in school policy, contact with parents, and satisfaction with parental involvement [20].

The main objective relationship with the public schools is to build a better image of the school. Furthermore, he said that in detail there are eight goals to be obtained from the relationship with the public, namely: (1) to inform the public about the school; (2) to estiblish confidence in the school; (3) to rally support for proper maintenance of the education program; (4) to develop an awareness of the importance of education in a democracy; (5) to improve the partnership concept by uniting parents and teachers in meeting the education needs of children; (6) to integrate the home, school, and community in improving education opportunities for all children; (7) to evaluate the offering of the schools and the needs of the children of the community; and (8) to correct misunderstanding about the aim and objectives of the schools [21].

Noting the role of principal leadership in communications and empower the role of parents for each child, then surely this parenting program does not just make parents empowered in activities organized by institutions of early childhood education course. But also includes endeavor role of parents in educating at home. That is education of parents do at home, or more commonly referred to as nurturing harmony and support the educational process at school. So with that aim that the process of education of children running optrimal more could be achieved because of the involvement of parents.

\section{CONCLUSION}

Principal leadership in early childhood education with psycho-religious approach is effective in establishing communication, interaction, and harmonization with parents to support and encourage the growth and development of children optimally, both in early childhood education institutions and at home. Parenting program is a series of programs that encouraged schools to optimize the role of parents in supporting and making parents empowered in activities organized by school at home. The parenting programs were implemented in five activities, i.e. group parent meetings; involvement of parents in the group; parental involvement in the event together; consultation of parents; and home visits.

\section{REFERENCES}

[1] Directorate of PAUD, Guidelines for the implementation of Early Childhood Education. familybased, Jakarta: Directorate of PAUD, General Directorate of PAUDNI, Ministry of National Education, Republic of Indonesia, Jakarta, 2012.

[2] Sumarsono, Parent Participation In Improving The Quality of Education In Primary Schools And Madrasah. Ph.D Thesis, Universitas Negeri Malang, 2016.

[3] I. Arifin, Leadership In Learning Innovation Centers: A Case Study Of The National Excellence's Early Childhood Education Of Anak Saleh Malang, Aditya Media, Yogyakarta, 2012.

[4] G.W. Olsen, M.L. Fuller, eds., Home-School Relations: Working Successfully With Parents And Families, 3rd ed, Pearson/Allyn and Bacon, Boston, 2008.

[5] A.T. Henderson, N. Berla, National Committee For Citizens In Education, Eds., A New Generation Of Evidence: The Family Is Critical To Student Achievement, National Committee for Citizens in Education, Columbia, Md., 1994.

[6] Erica, Z. Naimie, R.A. Abuzaid, S.H. Halili, S. Siraj, Parental Involvement In Children Education: Why Does It Make A Difference?, Taylor Francis Group. (2015) 139-144.

[7] R. Hariawan, Management Parenting Program On The National Excellence Of ECE: Multi Site Studies ECE Anak Saleh And ECE Firdaus Saleh in Malang. Master Thesis., Universitas Negeri Malang, 2011.

[8] Nuriati, Implementation Of Parenting Education Program For Parents Of Young Children. Master Thesis., Universitas Negeri Malang, 2013.

[9] Purnamawati, Development Of Transformative Learning Model On Parenting Education Program In Early Childhood Education Institutions. Master Thesis., Universitas Negeri Malang, 2014.

[10] D. E.S, Parenting Education In Support Of Early Childhood Learning. Ph.D Thesis., Universitas Negeri Malang, 2015.

[11] Wahjosumidjo, School Leadership: Overview Of Theoretical And Problems, PT. Raja Grafindo Persada, Jakarta, 2011.

[12] Baharuddin, Umiarso, Islamic Educational Leadership, Ar-Ruzz Media, Jogjakarta, 2012.

[13] Wirawan, Leadership: Theory, Psychology, Organizational Behavior, Applications, And Research, PT. Raja Grafindo Persada, Jakarta, 2014.

[14] G. Yukl, Leadership In Organization, 7th Edition, CA: Pearson, San Francisco, 2010.

[15] J. Rood, Leadership In Early Childhood, Allen \& Unwin, Victoria, Australia, 2006.

[16] M. Ebbeck, M. Wadinayake, Early Childhood Professionals: Leading Today And Tomorrow, Maclennan \& Petty, Sidney, Australia, 2005.

[17] D. Campbell, G.. Palm, Campbell, D., \& Palm, G. F. (2004). Group Parent Education: Promoting Learning And Parent Support. United States of America: SAGE., SAGE, USA, 2004.

[18] T.. Kowalski, Kowalski, T.J. (2004). Public Relations In Schools, Pearson Merrill Prentice Hall, Inc, New 
Jersey, 2004.

[19] G. Olsen, M.. Fuller, Home School Relations: Working Successfully With Parents And Families, Pearson Education, Inc, Boston, USA, 2003.

[20] J. Scheerens, R. Bosker, The Foundations of Educational Effectiveness, Pergamon, New York, 1997.

[21] S.. Knezevich, Knezevich, S. J. (1984). Administration Of Public Education: A Sourcebook For Leadership And Management Educational Institution. (4th ed.)., 4th Ed, Harper \& Row, New York, 1984. 